\section{A Bioética Social como ferramenta contra o trabalho em condições análogas a de escravo}

\section{Ferreira, Sheila Alves}

Discente do Mestrado em Bioética, Univás, Brasil. e-mail: sheila.ferreira@ifsuldeminas.edu.br

PALAVRAS-CHAVE: Bioética Social, Bioética de Proteção, Bioética de Intervenção, Trabalho em Condições Análogas a de Escravo, Vulnerabilidade.

Introdução: A escravidão, no Brasil, existiu na época em que o país era colônia portuguesa, e sua abolição caminhou por um processo lento e gradual, culminando na Lei Áurea, que a extinguiu por completo. Contudo, atualmente, a sociedade enfrenta uma situação em que o trabalhador é colocado em condição análoga à escravidão. Com a falta de empregos, a população mais carente, sem qualificação profissional, acaba se sujeitando às exigências dos patrões, que desrespeitam os dispositivos legais e ferem a dignidade da pessoa humana, protegida pela Constituição Federal de $1988^{1}$. Muitos trabalhadores inseridos nessa situação sequer percebem que estão sendo explorados, acreditando que as condições oferecidas são legais e adequadas. São submetidos a trabalhos forçados ou jornadas exaustivas, e a condições degradantes de trabalho, restrição de sua locomoção e retenção no local de trabalho, que é crime tipificado pelo artigo 149, do Código Penal Brasileiro ${ }^{2}$. Nessa situação, o trabalhador perde, além de sua dignidade, sua autonomia, e torna-se vulnerável, sujeito aos abusos do empregador, que se aproveita de sua posição superior para obter força de trabalho, muitas vezes em troca apenas de subsistência, ou seja, comida e abrigo. A bioética social analisa o caso concreto de forma ampla, fundamentando-se nos direitos humanos, instituídos pela Declaração Universal dos Direitos Humanos (1948) que resgatou a ideia de dignidade humana. Essa bioética é pautada "na perspectiva de tentar solucionar conflitos éticos considerando a realidade social e econômica dos envolvidos e a situação de desigualdade e exclusão dos países em que eles vivem"3. Ramifica-se em Bioética de Intervenção e Bioética de Proteção. Esta "tem por base a proteção da integridade física, psíquica, social e patrimonial do indivíduo por parte do Estado, visando a garantir uma melhor qualidade de vida a todos, principalmente aos mais necessitados"3. É fundada no princípio da proteção, que atribui ao Estado o dever de proteger seus cidadãos. Aquela tem como base os direitos humanos e a concepção de justiça social, é voltada para os países periféricos e defende que o Estado deve intervir em benefício dos mais vulneráveis, devendo ser levados em consideração, elementos como responsabilidade, cuidado e solidariedade ${ }^{4}$. Diante do exposto, o objetivo do presente estudo é analisar a incidência do trabalho em condição análoga a de escravo no Brasil, e relacionar seu combate à bioética social. Método: $\mathrm{O}$ estudo é desenvolvido por meio de pesquisas exploratória e bibliográfica. Resultados: Conforme dados do Observatório Digital do Trabalho Escravo no Brasil ${ }^{5}$, de 2003 a 2017 foi apurado um total de 43.696 pessoas resgatadas de trabalhos em condições análogas a de escravo, ou seja, em média 2.913 pessoas por ano. Conclusões: A Bioética Social, que visa a proteção dos vulneráveis se apoiando nos direitos humanos, representada pela Bioética de Intervenção e pela Bioética de Proteção, deve ser aplicada aos casos concretos, como instrumento para proteger os vulneráveis desse tipo de abuso e degradação, violações da dignidade da pessoa humana. O Estado e a sociedade devem ser invocados a socorrer o vulnerável e reestabelecer a sua autonomia como trabalhador e cidadão.

AGRADECIMENTOS. Agradeço a meu orientador Manoel Araújo Teixeira pela transmissão de conhecimentos e pela disponibilidade em me atender sempre que necessito, aos demais docentes e colegas da Univás que contribuiram de alguma forma para minha construção de conhecimento até o momento, ao IFSULDEMINAS pela concessão de afastamento para que eu possa me dedicar integralmente ao programa do mestrado.

\section{REFERÊNCIAS}

[1]BRASIL. Constituição da República Federativa do Brasil de 1988. 1988. Disponível em: <http://www.planalto.gov.br/ccivil_03/constituicao/constitui caocompilado.htm>. Acesso em: 28 nov. 2017.

[2] Código Penal. Disponível em: $<$ http://www.planalto.gov.br/ccivil 03/decreto-

lei/Del2848compilado.htm>. Acesso em: 28 nov. 2017.

[3] JUCÁ, Roberta Laena Costa; ANDRADE, Denise Almeida de. Da bioética principialista à bioética social: estudo de cases da prática da eutanásia no Brasil. In: Congresso Nacional do CONPEDI, 2009. São Paulo - SP. Anais XVIII. nov. 2009. Disponível em: $<$ http://www.publicadireito.com.br/conpedi/manaus/arquivos /anais/sao_paulo/2923.pdf>.

Acesso em: 29 jun. 2017.

[4] GARRAFA, Volnei. Da bioética de princípios a uma bioética interventiva. Revista Bioética. 2005. $\mathrm{n}^{\mathrm{o}}$ 1. vol. 13. Disponível em:

$<$ http://revistabioetica.cfm.org.br/index.php/revista_bioetica/ article/view/97/102>. Acesso em: 28 nov. 2017.

[5] Observatório Digital de Trabalho Escravo. Disponível em: <https://observatorioescravo.mpt.mp.br>. Acesso em: 17 ago. 2018. 